УДК 332.145(477)

DOI: https://doi.org/10.37320/2415-3583/9.21

Вовк C.M.

доктор наук $з$ державного управління, доцент, Донецький національний медччний університет

ORCID: https://orcid.org/0000-0003-3883-1320

Вовк Т.В.

викладач,

Донецький державний університет управління ORCID: https://orcid.org/0000-0002-0946-8473

\title{
ФОРМУВАННЯ КОНКУРЕНТНОГО СЕРЕДОВИЩА У СОЦІАЛЬНІЙ СФЕРІ УКРАЇНИ
}

\begin{abstract}
Однією з важливих проблем розвитку конкурентного середовищз в регіонах України є соиіальна сфера. Формування конкурентного середовища соиіальної сфери повинно охоплювати не тільки традиційні ринки, а й може сприяти вирішенню багатьох сочіальних проблем, які стосуються суспільства у цілому. Слід відзначити, щзо поступово, у міру продовження економічних реформ, здійснюватиметься перерозподіл функцій між органами виконавчої влади, органами місиевого самоврядування, підприємствами, установами й організаціями у сфері будівниитва, реконструкиії та утримання житла з метою їх децентралізації. Для розроблення стандартів сочіального захисту населення в сучасних економічних умовах необхідно впроваджувати інновації, спрямовані на підвищення продуктивності ресурсів, які роблять підприємства й організації більш конкурентоздатними.
\end{abstract}

Ключові слова: конкурентне середовище, соціальна сфера, регіони, економіка краӥни, навколишнє середовище, ідентифікація, виробництво, комунальні послуги.

Постановка проблеми. Процес формування конкурентного середовища повинен охоплювати не тільки традиційні ринки. Конкуренція може сприяти вирішенню багатьох соціальних проблем, тобто проблем, що стосуються всього суспільства (всього населення регіону).

Традиційно вважається, що вирішення соціальних проблем - це винятково прерогатива держави, а підприємці лише несуть додаткові витрати, що призводять до підвищення цін і зниження конкурентоздатності бізнесу. Проте світовий досвід свідчить, що саме розвиток соціальної сфери призводить до підвищення рівня життя населення та зростання економіки країни у цілому.

Аналіз останніх досліджень і публікацій. На сучасному етапі розвитку цивілізації проблеми досягнення та підтримання високого рівня міжнародної конкурентоспроможності набувають якісно нового змісту, що зумовлено, $з$ одного боку, посиленням процесів глобалізації ринків та транснаціоналізації економічних відносин, а 3 іншого - трансформацією традиційного набору чинників, здатних забезпечити конкурентні переваги у довгостроковій перспективі. В умовах економіки знань саме наявність високорозвиненого людського капіталу визначає здатність країни активізувати й ефективно використовувати наявні у неї ресурси.

Питання ідентифікації провідних чинників конкурентоспроможності країни піднімалися у працях багатьох світових науковців, серед яких: В. Петті, П. Буагільбер, А. Сміт, Д. Рікардо, Е. Хекшер, Б. Олін, М. Портер, Р. Ор, Ж. Валь- тер та ін. Розроблення теоретичного фундаменту концепції людського капіталу у працях Т. Шульца, Г. Беккера, Б. Вейсбройда, Д. Мінцера, Л. Ханса послужило основою для низки досліджень під авторством Дж. Герардуса, А. Гігеля, А. Вілдовича, Д. Трабольда, А.І. Юрьєва та ін., в яких людський капітал почав розглядатися не лише як найцінніший ресурс сучасного суспільства, а й як активатор усіх факторних умов конкурентоспроможності.

У сучасних умовах розвитку конкурентоспроможності регіону та вирішенню соціальних проблем приділяється значна увага вітчизняних та закордонних науковців: 3.В. Герасимчука, С.М. Вовк, Л.М. Зайцевої, Г.Б. Поляка та ін.

Мета статті полягає у дослідженні проблем розвитку соціальної сфери в Україні та визначенні передумов формування іiі конкурентоспроможності, основних напрямів удосконалення чинного законодавства та шляхів його поліпшення. Для досягнення означеної мети потрібно вирішити такі завдання: розкрити зміст поняття «конкурентоспроможність у соціальній сфері»; розробити комплекс дій щодо збереження та вдосконалення навколишнього середовища складника конкурентоспроможності комунальної сфери країни.

Виклад основного матеріалу. Досить розповсюдженим $є$ переконання, що суспільству неминуче доводиться шукати компроміс між екологією й економікою. Серед підприємців давно сформувалися переконання, що закони про охорону навколишнього середовища завдають шкоди конкурентоздатності фірм. Іншими словами, держава 
намагається нав’язати тверді стандарти, а підприємці - ухилитися від них.

Однак це невірно, адже, крім самих законів про навколишнє середовище, ні технології, ні процеси, ні потреби покупців не є фіксованими, інакше дані закони дійсно призводили б до зростання витрат. Але підприємці діють в умовах динамічної конкуренції, а не у статичному світі. Вони постійно шукають нестандартні відповіді на тиск, що здійснюється на них із боку конкурентів, споживачів та законодавців.

Належним чином розроблені стандарти щодо захисту навколишнього середовища можуть ініціювати впровадження інновацій, що дають змогу знизити сумарні витрати виробництва відповідної продукції або підвищити їі споживчу цінність. Такі інновації дають підприємцям змогу більш ефективно використовувати сукупність чинників виробництва (починаючи із сировини і закінчуючи енергією та робочою силою), компенсуючи тим самим витрати, пов'язані з необхідністю виконання законів щодо захисту навколишнього середовища. У кінцевому підсумку таке підвищення продуктивності ресурсів робить підприємства більш конкурентноздатними, а не навпаки [1].

Як правило, політики, підприємці розглядають законодавство про захист навколишнього середовища тільки 3 погляду його впливу на зростання витрат виробництва, зовсім виключаючи можливість суттєвого виграшу від підвищення продуктивності в результаті впровадження інновацій. Саме тому їхні дії найчастіше призводили до зовсім невиправданого зростання витрат й уповільнення прогресу з питань захисту навколишнього середовища.

Інакше кажучи, законодавці приймали закони, що стримують упровадження інновацій. Підприємці, своєю чергою, противляться виконанню цих законів замість того, щоб упровадити нововведення в технологічний процес. Звідси судові розгляди, тобто додаткові витрати для підприємства.

Насправді забруднення навколишнього середовища найчастіше $є$ формою економічного марнотратства, коли відходи виробництва, шкідливі речовини й ті або інші форми енергії потрапляють у навколишнє середовище у вигляді забруднень із наявністю ознак неповного, неефективного або марнотратного використання ресурсів. Більше того, у результаті таких викидів підприємствам найчастіше доводиться сплачувати додаткові витрати на усунення їхніх наслідків (наприклад, вивіз на смітник або повторну переробку відходів виробництва). Ці витрати позначаються на ціні продукції, нічого не додаючи до іiі споживчої цінності.

Неефективність використання ресурсів у компанії 3 найбільшою очевидністю виявляється у формі неповного використання матеріалів і недостатньої дієвості методів управління процесами, результатом яких $\epsilon$ необов'язкові втрати, дефекти і необхідність збереження великих запасів матеріалів. Але існує і багато інших прихованих витрат, що виявляються вже після продажу продукції.

Наприклад, тара, яку дистриб'юторам або покупцям доводиться викидати, також свідчить про неефективне використання ресурсів і зайвих витрат виробництва. Споживачам доводиться нести додаткові витрати, коли вони користуються товарами, що забруднюють навколишнє середовище або споживають надмірну енергію. Ресурси витрачаються неефективно й тоді, коли викидаються продукти, що містять матеріали, придатні для використання, і коли споживачі сплачують - прямо або опосередковано - за утилізацію продуктів [2].

Коли йдеться про захист навколишнього середовища, то головна увага приділяється контролю забруднень на основі проведеної утилізації відходів або викидів, що пов'язано із зазначеними витратами. В останні роки найбільш передові компанії i фахівці із захисту навколишнього середовища висунули концепцію запобігання забрудненню (яка іноді називається відновленням джерел). При цьому для обмеження ступеня забруднення ще до того, як воно відбулося, використовуються такі підходи, як заміна матеріалів i процесів із замкнутим циклом.

Іншим словами, підприємці повинні звернути увагу на альтернативні витрати (або витрати невикористаних можливостей), а не витрачати додаткові кошти на нейтралізацію або ліквідацію забруднень. Вони повинні зрозуміти, що захист навколишнього середовища i конкурентоздатність нероздільні. М. Портер виділяє шість найважливіших причин, що спричиняють необхідність прийняття законів про охорону навколишнього середовища:

- щоб здійснювати на компанії тиск, що змушує впроваджувати інновації. Відзначимо важливу роль зовнішнього тиску в подоланні організаційної інертності і стимулюванні творчого мислення;

- щоб поліпшити якість навколишнього середовища тоді, коли інновації і результуючі поліпшення продуктивності ресурсів не повністю компенсують витрати, пов'язані з виконанням вимог законів, або в тому разі, коли потрібний певний час для вивчення заходів, спрямованих на зниження загальної вартості впровадження інноваційних рішень;

- щоб довести до відома компанії про найбільш ймовірні випадки неефективного використання ресурсів і про потенційні сфери технологічних удосконалень;

- щоб підвищити ймовірність того, що інновації, які впроваджуються в технологічні про- 
цеси чи продукцію, не позначаються негативно на стані навколишнього середовища;

- щоб створювати у споживачів і компаній відчуття необхідності боротьби 3 забрудненням навколишнього середовища до того часу, поки вони цілком не відчують неефективність використання ресурсів і пов' язаний із ним шкідливий вплив на навколишнього середовище;

- сприяти прийняттю компаніями інноваційних рішень захисту навколишнього середовища. При цьому компаніям, що намагаються уникнути капіталовкладень, спрямованих на захист навколишнього середовища, недвозначно дають зрозуміти, що подібні дії призведуть лише до погіршення їхніх позицій. Закони щодо захисту навколишнього середовища $є$ для інноваційних компаній свого роду буфером, поки не затвердилися нові технології і поки внаслідок навчання не знизилися витрати на впровадження цих технологій [3].

Ще одним яскравим прикладом того, як конкуренція допомагає вирішувати соціальні проблеми, $€$ житлово-комунальна сфера.

Комунальні послуги - це певні товари, що не мають замінників i абсолютно не еластичні до попиту. Задіяти механізм попиту та пропозиції у відношенні комунальних послуг навряд чи можливо. За відсутності конкурентної пропозиції нееластичних до попиту товарів механізми попиту та пропозиції не діють, і ціни на ці послуги формуються виходячи 3 витрат, що несе постачальник, а вони можуть бути як завгодно великими.

Комунальні послуги задовольняють життєво важливі потреби людини, у систему комунальних послуг входять ведення житлового господарства, забезпечення роботи водопроводу і каналізації, енерго-, тепло- і газопостачання, служби очищення і прибирання території. Економічною відмінністю даної групи послуг $є$ суспільний характер потреб у них, що зумовлюються такими властивостями комунальних послуг: унікальним характером послуг; колективним, знеособленим характером споживання послуг; наявністю матеріального носія; відсутністю індивідуального вибору послуг споживачами; винятково високою роллю кліматичного і географічного чинників у формуванні потреби в даних послугах.

Слід зазначити, що, незважаючи на зазначені чинники спільності комунальних послуг, кожна 3 них унікальна по-своєму, тобто кожній iз них властива відмінна риса, що не дає змоги ідентифікувати їх разом. Наприклад, задоволення потреби в одній послузі не скорочує потреби людини в іншій. Деякі послуги виникають як чисто колективні потреби, інші, навпаки, формуються на основі індивідуальних бажань. Споживання одних послуг відбувається індивідуально, інших колективно, а третіх - безособово всім міським співтовариством [4].
Принципи і методи формування цін у ЖКГ в умовах централізованої економіки формувалися на основі того, як вони визначалися на підприємстві, тобто у виробництві. Такий підхід неминуче призводив до того, що за базу цін приймалися витрати на виробництво. Звідси - планування у сфері житлово-комунальних послуг витратного методу ціноутворення, що зазнав критики ще за планової економіки.

За сформованого нормативно-витратного підходу ЖКХ потрібно приблизно 18\% середнього доходу родин, що користуються основним набором житлово-комунальних послуг у державному муніципальному і багатоквартирному приватному житловому фонді. На субсидування ЖКХ спрямовується від 40\% до $80 \%$ ресурсів місцевих бюджетів і значна частка бюджетів суб'єктів України.

Витратний механізм $є$ одним із ключових моментів, що заважають реформуванню галузі. Реформування житлово-комунального господарства припускає зміну системи управління й обслуговування житлового фонду 3 метою зниження витрат. Саме за рахунок зниження собівартості, а не за рахунок підвищення тарифів пропонується виключити бюджетні дотації. Конкуренція є необхідним елементом проти затратного механізму, що стимулює зниження собівартості надання послуг i підвищення їхньої якості, тому що саме конкуренція змушує різні підприємства шукати шляхи зниження витрат і підвищення якості наданих послуг, витісняючи із цього сектору ті підприємства, які не в змозі зробити це.

Стимулювати розвиток конкурентного середовища можна через конкурсні відбори, використовуючи при цьому спеціальну процедуру, що забезпечує їх відкритість та об'єктивність, що, своєю чергою, створює всі необхідні передумови для вибору найкращої з наявних організацій. Саме механізми конкурсного відбору здатні систематично усувати із цієї сфери діяльності найменш ефективно працюючі організації, заміняючи їх іншими, більш перспективними [5].

Серйозний вплив на розвиток конкурентного середовища житлово-комунальної сфері здійснює зростання кількості товарів власників житла (ТВЖ). Це зумовлено тим, що ТВЖ як реальні власники найбільше зацікавлені в раціональному використанні наявних у них ресурсів (надання якісних послуг за мінімальними цінами). 3 іншого боку, наявність достатньо великої кількості власників збільшує необхідність уведення систематичного контракту за дотримання єдиних стандартів стану житлового фонду незалежно від того, хто є власником даного житла.

Найважливішим напрямом розвитку конкуренції є розмежування функцій власника - керуючої організації (замовники організації, що надає послуги (підрядники)). 
Сьогодні процес формування конкурентного середовища в Донецькій області не завершено. Поділ функцій замовника і підрядника продовжується. Нині служби замовника керують 70\% усього муніципального житлового фонду. Однак залишається монополія держави на управління житловим фондом. Це створить передумови для формування принципово нової форми управління власністю.

В області створено понад 500 ТВЖ, багато 3 них віддають перевагу професійним керуючим i невеликим фірмам, послуги яких виявляються менш дорогими і більш якісними. Продовжується проведення конкурсів для відбору підрядних організацій з обслуговування муніципального житлового фонду.

Таким чином, конкуренція на ринку житлових послуг сприяє розвитку альтернативних форм управління житловим фондом, що дасть змогу знизити витрати i, відповідно, вартість послуг, що стануть доступними для більшої частини населення. А це, своєю чергою, означає зменшення соціальних виплат і зниження навантаження на місцевий бюджет.

Цікавим $є$ досвід застосування економічних підходів до відновлення і реставрації пам'яток історії та культури. Найчастіше подібні будинки знаходяться у центральній частині міста, мають гарну транспортну і пішоходу структуру, тому виконання державного завдання зі збереження пам'яток історії можна покласти на приватних інвесторів із подальшою передачею об'єкта в користування. При цьому програма реставраційних робіт складається адміністрацією області та муніципалітетом, і інвестор зобов'язаний дотримуватися всіх запропонованих вимог. Протягом останніх років проведено низку заходів із залучення інвестицій у цю сферу, що підтвердили дії підприємців до подібного роду інвестицій.

Висновки. Таким чином, у нашому дослідженні ми задавалися ціллю охопити всі соціальні проблеми, однак наведені приклади показують, що розвиток конкуренції у сферах, що традиційно $\epsilon$ не досить привабливими для бізнесу, можливий і цілком прийнятий. Конкуренції вдається вирішувати соціальні проблеми, незважаючи при цьому обмежені бюджетні ресурси.

3 огляду на це, потребують конкретніших досліджень аналіз та оцінка допущених помилок у соціально-політичній діяльності і розроблення концептуальних та програмних засад цивілізованого формування й наповнення української моделі соціальної політики держави, яка б відповідала прагненням суспільства та вимогам прогресивного людського розвитку. Наведене дає підстави для висновку, що формування цивілізаційних засад сучасної соціальної політики $є$ однією $з$ нагальних потреб сьогодення. Доповнення інструментарію $є$ подальшим напрямом наукових досліджень у розвитку сучасної науки.

\section{Список використаних джерел:}

1. Сазонця І.Л. Інвестиції стратегії конкурентоспроможної економіки : монографія. Дніпропетровськ : Наука і освіта, 2012. $416 \mathrm{c}$.

2. Герасимчук 3.В., Вахович I.М. Організаційно-економічні механізм формування та реалізації стратегії розвитку регіону : монографія. Луцьк : ЛДТУ, 2012. 248 с.

3. Пакулін С.Л. Концепція управління потенціалом соціально-економічного розвитку регіону. Science and education LTD. 2015. № 5. P. 5-7.

4. Яцишина I.В. Соціальне спрямування інноваційної економіки: тенденції, наслідки : монографія. Кам'янецьПодільський : ФОП Сисин Я.І., 2012. 368 с.

5. Лопушняк Г.С. Державна соціальна політика як передумова економічного розвитку України : монографія. Львів : ЛРІДУ НАДУ, 2011. 372 с.

6. Пакуліна А.А., Пакулін С.Л., Корсунський Г.Ю. Підвищення сталості соціально-економічного розвитку і забезпечення економічної безпеки регіонів. Вісник економіки транспорту і промисловості. 2015. № 4. С. 215-219.

7. Макарова О.В. Людський розвиток в Україні: соціальні та демографічні чинники модернізації національної економіки : колективна монографія / за ред. Е.М. Лібанової. Київ : НАН України, 2012. 320 с.

8. Панченко М. Соціальна сфера і соціальна політика та їх співвідношення в аспекті державного управління соціальною сферою. Начіональна бібліотека Украӥни імені В.I. Вернадського. URL : http://www.nbuv.gov.ua/portal/Soc Gum/ Apdu_o/2009_1/R_5/Panchenko.pdf (дата звернення: 21.10.2019).

\section{References:}

1. Sazoncya I.L. (2012) Investy'ciyi strategiyi konkurentospromozhnoyi ekonomiky [Investment in a competitive economy strategy]. Dnipropetrovs ` $k$ : Nauka i osvita. p 416.

2. Gerasymchuk Z.V., Vakhovich I.M. (2012) Organizacijno-ekonomichni mexanizm formuvannya ta realizaciyi strategiyi rozvy`tku regionu [Organizational and economic mechanism of formation and implementation of regional development strategy]. Lucz $k$ : LDTU p.248

3. Pakulin S.L. (2015) Koncepciya upravlinnya potencialom social'no-ekonomichnogo rozvy'tku regionu [Concept of managing the potential of socio-economic development of the region]. Science and civilization: materials of the XI International scientific and practical. Sheffield: Science and education LTD, vol. 5 pp. 5-7.

4. Yatsyshina I.V. (2012) Social’ne spryamuvannya innovacijnoyi ekonomiky`: tendenciyi, naslidky`[Social orientation of the innovation economy: trends, consequences]. Kamianets-Podilskyi: FOP Sysin Y.I. p. 368. 
5. Lopushniak G.S. (2011). Derzhavna social 'na polity 'ka yak peredumova ekonomichnogo rozvy ’tku Ukrayiny’[ State social policy as a prerequisite for economic development of Ukraine] Lviv: LRIDA NADU p. 372.

6. Pakulin A.A., S.L. Pakulin, G.Yu. Korsuns`ky`j (2015). Pidvy`shhennya stalosti social’no-ekonomichnogo rozvy `tku $i$ zabezpechennya ekonomichnoyi bezpeky` regioniv. [Improving the sustainability of socio-economic development and ensuring the economic security of regions]. Bulletin of the economy of transport and industry. Visny 'k ekonomiky` transportu i promy`slovosti vol. 4 pp. 215-219.

7. Makarova O.V. Lyuds 'ky j rozvy tok v Ukrayini: social 'ni ta demografichni chy `nny 'ky` modernizaciyi nacional noyi ekonomiky .[Human Development in Ukraine: Social and Demographic Factors of the Modernization of the National Economy] Institute of Demography and Social Research. p. 320.

8. Panchenko M. (2009) Social 'na sfera i social na polity 'ka ta yix spivvidnoshennya $v$ aspekti derzhavnogo upravlinnya social noyu sferoyu. [Social sphere and social policy and their correlation in the aspect of state management of the social sphere]. National Library of Ukraine named after VI Vernadsky. Available at: http://www.nbuv.gov.ua/portal/Soc_Gum/Apdu_o/ 2009_1/R_5/Panchenko.pdf (accessed 21 October 2019).

Vovk Svetlana

Donetsk National Medical University

Vovk Tatiana

Donetsk State University of Management

\section{FORMATION OF COMPETITIVE ENVIRONMENT IN SOCIAL SPHERE OF UKRAINE}

One of the important problems of development of competitive environment in the regions of Ukraine is the social sphere. Developing a competitive social environment should not only cover traditional markets, but can also help to address many social problems that affect society as a whole. It should be noted that as economic reforms continue, functions will be redistributed between the executive, local self-government, enterprises, institutions and organizations in the field of construction, reconstruction and maintenance of housing in order to decentralize them. In order to develop standards for social protection of the population in today's economic environment, it is necessary to introduce innovations aimed at improving the productivity of resources, which make enterprises and organizations more competitive. Most inefficient use of resources at a company manifested in the form of incomplete use of materials and insufficient effectiveness of process management methods, which result in unnecessary losses, defects and the need to conserve large inventories of materials. But there are many other hidden costs that come to light after the sale of the product. Consumers have to incur additional costs when they use goods that pollute the environment or consume excess energy. Resources are inefficiently spent even when products containing usable materials are thrown away and consumers are paid - directly or indirectly - for the disposal of the products. The principles and methods of pricing in utilities in a centralized economy were formed on the basis of how they were determined at the enterprise, that is, in production. This approach inevitably led to the fact that production costs were taken as the price base. Hence, housing and utility planning is a cost-pricing method that has been criticized in the languages of the planned economy. Despite the fact that the problems of functioning of the housing and communal complex are constantly in the focus of close attention of the state administration of Ukraine, however, no serious positive changes in this area have occurred. This can be explained by the fact that the housing and communal services system is an infrastructure component of the system of state administration and local self-government, but it is invested according to the final principle. This is primarily due to the lack of a clear division of powers between state authorities and local self-government bodies, when practically no issues are considered at the state level and, consequently, issues related to the activity of housing and communal services are not solved, and their solutions are not resolved. completely translated into the shoulders and financial and economic bases of local governments - local councils. The main objects of housing and communal services are owned by territorial communities and directly - in the sphere of management of local self-government bodies. Under such conditions, it is not necessary to speak about full financing of the needs of utilities. Thus, competition in the housing market promotes the development of alternative forms of housing management, which will reduce costs and, consequently, the cost of services that will be available to the majority of the population. And this, in turn, means reducing social payments and reducing the burden on the local budget.

Key words: competitive environment, social sphere, regions, country's economy, environment, identification, production, utilities.

JEL classification: N3, O21, P11. 